\title{
CHARACTERIZATION OF CUCURBIT PRODUCTION SYSTEMS AND DISEASE PREVALENCE IN MUNICIPALITIES IN PERNAMBUCO ${ }^{1}$
}

\author{
GERFFESON THIAGO MOTA DE ALMEIDA SILVA², RAYANNE MARIA PAULA RIBEIRO ${ }^{3}$, AURÉLIO PAES \\ BARROS JÚNIOR $^{3}$, LINDOMAR MARIA DA SILVEIRA ${ }^{3 *}$, PEDRO MARTINS RIBEIRO JÚNIOR ${ }^{4}$, NEILZA REIS \\ CASTRO DE ALBUQUERQUE
}

\begin{abstract}
Cucurbits have great economic, nutritional and social importance in the Brazilian semiarid region. In this region, many factors can result in reduced productivity of these crops, especially fungal and viral diseases. Therefore, knowledge of cucurbits is crucial for proper disease management. The objective of this work was to identify the major diseases of cucurbits grown in some municipalities in the Hinterland of the state of Pernambuco. Thus, plant samples were collected with symptoms in crops in the municipalities of Salgueiro, Serra Talhada, Floresta, Petrolândia, Ibimirim, Custódia and Inajá. A questionnaire was also applied to gather information about the production profile of producers. Seven fungal pathogens infecting cucurbits were identified: Pseudoperonospora cubensis, Colletotrichum sp., Podosphaera xanthii, Rhizoctonia solani, Didymella bryoniae, Fusarium sp. e Alternaria sp., and three viruses as well: Papaya ringspot virus watermelon strain (PRSV-W), Watermelon mosaic virus (WMV), Zucchini yellow mosaic virus (ZYMV). It was found that in small crops, there is limited search for technical information om cropping, and these crops originate mostly from native seeds, in contrast to medium and large producers, who use improved cultivars. The melon and watermelon crops are the most commercially exploited, while pumpkins are used in subsistence agriculture. As for plant health problems, most respondents reported knowing the main diseases that occur in crops and perform disease control based on personal experience and / or through the help of the technical assistance provided by agricultural stores. In a few cases, in large farms, there was an agronomist to assist in this type of control.
\end{abstract}

Keywords: Plant pathology survey. Citrullus. Cucurbita. Cucumis. Fungi. Viruses.

\section{CARACTERIZAÇÃO DOS SISTEMAS DE PRODUÇÃO DE CUCURBITÁCEAS E DA PREVALÊNCIA DE DOENÇAS EM MUNICÍPIOS PERNAMBUCANOS}

RESUMO - As cucurbitáceas possuem grande importância econômica, nutricional e social no Semiárido brasileiro. Nesta região, diversos fatores podem acarretar em redução na produtividade dessas culturas, destacando-se as doenças fúngicas e viróticas, tornando-se necessário o conhecimento das mesmas para um adequado manejo. Assim, o objetivo desse trabalho foi identificar as principais doenças de cucurbitáceas produzidas em alguns municípios localizados no Sertão Pernambucano. Para tanto, foram coletadas amostras de plantas com sintomas em cultivos nos municípios de Salgueiro, Serra Talhada, Floresta, Petrolândia, Ibimirim, Custódia e Inajá. Também foi aplicado um questionário visando obter informações do perfil produtivo dos produtores. Identificou-se sete patógenos fúngicos infectando cucurbitáceas, Pseudoperonospora cubensis, Colletotrichum sp., Podosphaera xanthii, Rhizoctonia solani, Didymella bryoniae, Fusarium sp. e Alternaria sp., e três vírus, Papaya ringspot virus type watermelon (PRSV-W), Watermelon mosaic virus (WMV), Zucchini yellow mosaic virus (ZYMV). Verificou-se que nos pequenos cultivos, a busca por informações para cultura implantada ainda é limitada, sendo esses cultivos, em sua maioria, provenientes de sementes crioulas em contraste com médios e grandes produtores que utilizam cultivares melhoradas. A cultura do melão e da melancia são as mais exploradas comercialmente e as abóboras utilizadas na agricultura de subsistência. Quanto a problemas fitossanitários, a maior parte dos entrevistados relatou conhecer as principais doenças que ocorrem na cultura e realizam controle com base na experiência pessoal e/ou através do auxilio da assistência técnica fornecida por lojas agropecuárias. Em poucos casos, em propriedades de grande porte, havia um engenheiro agrônomo para auxiliar nesse tipo de controle.

Palavras-chave: Levantamento fitopatológico. Citrullus, Cucurbita. Cucumis. Fungos. Vírus.

\footnotetext{
"Corresponding author

${ }^{1}$ Received for publication in $02 / 06 / 2015$; accepted in $04 / 25 / 2016$.

Extracted from the master thesis of the first author.

${ }^{2}$ Department of plant science, Universidade Federal do Ceará, Fortaleza, CE, Brazil; gtmas@hotmail.com.

${ }^{3}$ Department of Plant Sciences, Universidade Federal Rural do Semi-Árido, Mossoró, RN, Brazil; rayanne_tab@hotmail.com, aurelio.barros@ufersa.edu.br, lindomarmaria@ufersa.edu.br.

${ }^{4}$ Empresa Brasileira de Pesquisa Agropecuária, Embrapa Semiárido, Petrolina, PE, Brazil; pedro.ribeiro@embrapa.br.

${ }^{5}$ Academic Unit of Serra Talhada, Universidade Federal Rural de Pernambuco, Serra Talhada, PE, Brazil; neilzacastro@gmail.com.
}

Rev. Caatinga, Mossoró, v. 29, n. 3, p. 774 - 779, jul. - set., 2016 


\section{INTRODUCTION}

In Brazil, cucurbits account for $23 \%$ of all vegetables sold, and there are several species that are economically important in the national supply as a result of high consumer acceptance, e.g., melons (Cucumis melo L.), watermelons [Citrulluslanatus (Thunb.) Matsum. \& Nakai] and pumpkins (Cucurbita sp.) (FILGUEIRA, 2008). In general, many of these are still produced in relatively small quantities, targeting only local consumption, and they are not significantly taken into account in production statistics, even though they are essential items in the staple diet of many populations (SANTI, 2013). This reality can be seen, for example, in some hardly technified areas of Brazil's northeast, and the main vegetable crops of the Cucurbitaceae family (watermelon, melon, squash and pumpkin) are always present in their cultivation areas.

In the state of Pernambuco, the profile of cucurbit producers varies depending on the type of farm where cultivation takes place, and it is influenced by factors such as availability of water and financial resources. Farming by smallholders generally has a low technological level, given the cost of production factors and the often limited availability of water. In irrigated regions in the Hinterland in the state of Pernambuco, medium and large producers mainly grow watermelon and melon, using technologies such as improved cultivars and irrigation, as well as post-harvest controls, aiming at fruit quality and making room for the increase in sales to other regions of Brazil and the world; for example, melon is exported to Spain (MDIC, 2015).

However, most cucurbits are severely affected by diseases, and the expansion of cultivation areas in the state has favored the aggravation of existing diseases, which have become economically important, as well as the emergence of new diseases.
The following viroses are particularly worth of notice: zucchini yellow mosaic virus (ZYMV); papaya ringspot virus - watermelon strain (PRSV$\mathrm{W}$ ); watermelon mosaic virus (WMV), cucumber mosaic virus (CMV), squash mosaic virus (SqMV); fungal such as powdery mildew (Podosphaera xanthii), downy mildew (Pseudoperonospora cubensis), gummy stem blight (Didymella bryoniae), Fusarium wilt (Fusarium oxysporum), among others (KUROSAWA; PAVAN, 1997).

Identification of the main diseases affecting cucurbit crops in this region of the state of Pernambuco is required to establish integrated management strategies, both preventive and curative, thus economically enabling the cultivation of these crops in the region, especially because there are few studies on this theme. Given the above, the aim of the present study was to identify the most frequent pathogens in cucurbit crops in Hinterland towns of Pernambuco and characterize the production profile in these crops.

\section{MATERIAL AND METHODS}

The study was conducted from March 2013 to March 2014 in hinterland towns of Pernambuco, where visits were carried out to production fields in the municipalities of Salgueiro (production areas of squash and pumpkin), Serra Talhada (production areas of squash, pumpkin, watermelon and melon), Floresta (production areas of melon), Petrolândia (production areas of melon, watermelon and pumpkin), Ibimirim (production areas of watermelon), Inajá (production areas of melon and watermelon) and Custódia (production areas of watermelon, meluite, pumpkin and melon). These municipalities are located in the hinterland of the state of Pernambuco (Figure 1).

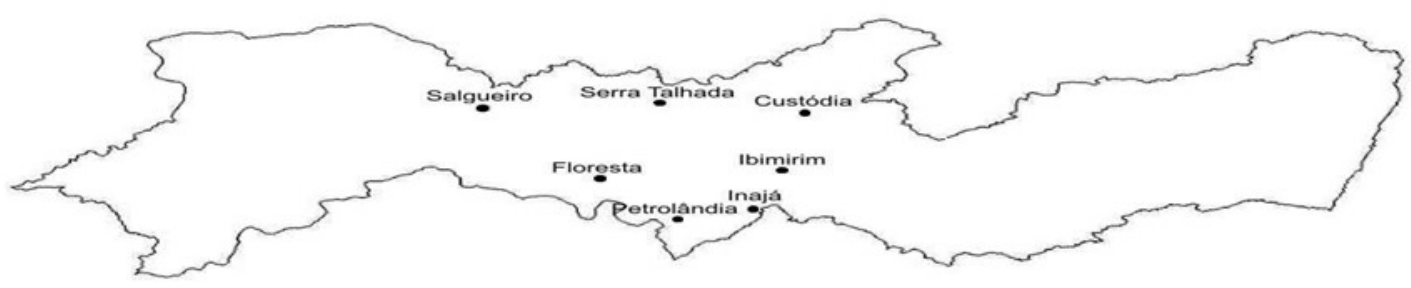

Figure 1. Map of the State of Pernambuco indicating the towns where the major diseases in cucurbits were identified. 
During the visits, a questionnaire was applied to producers in order to obtain information on production, management systems and major existing plant pathology problems in areas with cucurbit crops. The 30 production areas that had been visited were sampled based on the importance of some of these crops for the region. They included small (up to $1 \mathrm{ha}$ ) and mid-sized areas (2-3 ha), where subsistence agriculture takes place, as well as larger areas ( $>4 \mathrm{ha})$, where production is intended to meet the needs of more demanding markets, both domestic and foreign, for example, melon crops, which are exported to Spain.

In each crop field, after visual evaluation, samples were collected from plants with symptoms of infection by plant pathogens and soil was sampled from the rhizosphere of plants with symptoms of wilt. Samples of plants with symptoms of virus infection were sent to the Laboratory of Plant Virology, Federal University of Ceará (LabVV/UFC) for serological identification of the species of virus present in the samples. The others were sent to the Plant Pathology Laboratory at the Unidade Acadêmica de Serra Talhada, Federal Rural University of Pernambuco - UAST / UFRPE, where visual diagnosis was performed of symptoms and microscopic fungal structures produced in infected tissues. This diagnosis was performed directly for biotrophic organisms such as mildew and oidium or after isolation of pathogens in culture medium for facultative saprophytes.

The viruses in the samples were identified by indirect ELISA (Enzyme-Linked Immunosorbent Assay) serological tests, in accordance with the criteria adopted at LabVV, UFC (ALMEIDA; LIMA, 2001). Specific antisera were used for Papaya ringspot virus, watermelon strain (PRSV$\mathrm{W})$, Watermelon mosaic virus (WMV), Zucchini yellow mosaic virus (ZYMV) and Cucumber mosaic virus (CMV) and Agar Double-Diffusion was used against specific antiserum for Squash mosaic virus (SqMV). The fungal isolation procedure was performed according to the methodology described by Menezes and Silva-Hanlin (1997), which consisted of using plant tissue fragments cut in the transition region of the lesion, with surface disinfestation in $70 \%$ alcohol by 30 seconds, and transfer of the fragments to a sodium hypochlorite solution $(1.5 \%)$ for two minutes. The fragments were rinsed three times in sterile distilled water to remove excess hypochlorite. After this process, the fragments were put to dry on sterile filter paper. Then, they were plated in PDA culture medium and incubated for seven days at room temperature and alternating light $(12 \mathrm{~h}$ light/12 $\mathrm{h}$ dark $)$. After obtaining pure colonies with characteristics of the species under study, they were maintained in test tubes containing PDA.

For fungal isolation in soil samples, $10 \mathrm{~g}$ of the sample soil was used. It was added to an
Erlenmeyer flask containing $90 \mathrm{~mL}$ of sterile distilled water and subjected to homogenization in a magnetic stirrer at $120 \mathrm{rpm}$ for 30 minutes. Subsequently, serial dilutions were performed in series to obtain 1:10,000 dilution. Aliquots of $0.5 \mathrm{~mL}$ of soil solution were added to petri dishes containing PDA culture medium (Potato Dextrose Agar). The plates were incubated at $25^{\circ} \mathrm{C}$ under alternating light for a period of seven days. After obtaining pure colonies, strains were preserved in test tubes.

Slides were prepared for microscopic observation by using thoroughly cleaned glass slides where colonies fragments (obtained in culture medium) were placed, added to the blue dye Amman and, finally, coverslips were placed over the preparation. These slides were observed by light microscopy with $40 \mathrm{X}$ objective lens. To identify the genus/species, the criteria established by Rossman et al. (1994) were used.

\section{RESULTS AND DISCUSSION}

According to the questionnaire answered by the producers, $31.8 \%$ of the visited cucurbit production areas are not larger than 1.0 ha. In this study, they were identified as small farms; $54.5 \%$ of the areas had 3.0 ha on average (mid-size farms) and $13.7 \%$ measured between 4.0 and more than 100 ha (large farms). Melon and watermelon crops were found in farms of all sizes, and these crops were the most commercially exploited by large producers. Squash and pumpkin are mainly grown on small farms. In addition to crops from the Cucurbitaeae family, smallholders also grow cereals, vegetables and fruits for commercial purposes, such as cowpea, maize, cassava, passion fruit, peppers, lettuce and cilantro, among others. Family labor supply is prominent among these producers.

In small crops, farmers hardly ever search for technical information and many use their own experience, or ask for the help of neighbors and / or sales representatives of commercial agricultural products only when they experience difficulties in cultivation. About $90 \%$ of the Cucurbitaceae grown by small farmers are derived from native seeds that they maintain over multiple crops. By contrast, cucurbits produced by medium and large producers originate from seeds purchased from specialized companies. Family farmers use mineral and organic fertilizers or organic fertilizers only, while large producers use mineral fertilizers alone.

With regard to water for irrigation, the producers interviewed obtain water mainly from wells, rivers and dams, mainly depending on the availability of resources in each region. Most irrigation systems (62\%) consist of drip, but there are also crops irrigated with the use of grooves $(19 \%)$ and sprinklers (19\%).

For plant health problems, $86 \%$ of 
respondents reported knowing the key pests and diseases that occur in crops, and disease control is based on personal experience or with the help of technical assistance provided by agricultural product stores. As an exception, $10 \%$ of them, in some large farms, have the assistance of an agronomist to help in disease control. All respondents reported conducting regular inspections to verify the occurrence of plant pathology problems; however, diseased plants are often not eliminated. Eighty-five percent of producers control weeds. Most of them $(67 \%)$ reported using hand weeding for this purpose; a small part of them $(23 \%)$ uses chemical control while $10 \%$ do not use any control.

In the post-harvest phase, only one of the respondents reported using treatments to increase the durability of his products, namely a fungicide which is applied to the fruit stalk before the melon is stored for later export.

Based on the observation of symptoms and fungal structures and conduction of serologic testing, 10 pathogens were identified as infecting the cultivated cucurbits: seven fungi (Table 01) and three viruses (Table 02)

The most frequent disease was mildew, identified in all municipalities visited. Viral diseases were the second most frequent. There was high incidence of viral infections mainly in areas where there were aphids. The fungal diseases observed in crops included gummy stem blight (D. bryoniae), downy mildew ( $P$. cubensis), anthracnose (Colletotrichum sp.), powdery mildew ( $P$. xantii). They have been identified / isolated from the shoots of the plants. Rhizoctonia solani and Fusarium sp. were isolated from samples of roots and soil collected in the municipality of Ibimirim, where there were symptoms in coppices of intensive wilt end-cycle plants with and without apparent symptoms in the leaves.

Phytopathological surveys are very important because they aim to inform about the occurrence and frequency of diseases occurring in a particular crop, thus assisting in proper disease management. Specific surveys of diseases in cucurbits have been performed previously (REIS et al., 2005, Silva et al., 2006 SANTOS; CAFÉ FILHO 2006), yet there are few surveys that intended to identify different groups of pathogens in various crops. In the period from 2008 to 2010, Lima and Alves (2011) conducted a nationwide survey of viral diseases in cucurbits, covering 21 municipalities in seven states and the Federal District. However, in the State of Pernambuco, only the city of Petrolina was sampled, where the viruses PRSV-W, WMV, ZYMV, CMV and ZLCV were detected. In another work, in the Lower Basin of the São Francisco river, Silveira et al. (2009) conducted an extensive collection of cucurbit samples and found that the virus that occurred in greater incidence was PRSV-W, followed by PRSV-P and ZYMV.

Table 1. Survey of the main fungal diseases in cucurbits grown in hinterland municipalities of Pernambuco.

\begin{tabular}{|c|c|c|c|c|}
\hline \multirow[b]{2}{*}{ Municipality } & \multicolumn{2}{|c|}{ Cucurbit } & \multirow[b]{2}{*}{ Disease } & \multirow[t]{2}{*}{ Pathogen } \\
\hline & Scientific name & Common name & & \\
\hline \multirow{3}{*}{ Custódia } & Cucumis melo & Melon & Gummy stem blight & Didymella bryoniae \\
\hline & Citrullus lanatus & Watermelon & Powdery mildew & Podosphaera xanthii \\
\hline & & Melon & Powdery mildew & Podosphaera xanthii \\
\hline \multirow[t]{3}{*}{ Floresta } & Cucumis melo & & Anthracnose & Colletotrichum sp. \\
\hline & & Watermelon & wilt & Fusarium sp. \\
\hline & & & Powdery mildew & Podosphaera xanthii \\
\hline \multirow{3}{*}{ Ibimirim } & Citrullus lanatus & & & \\
\hline & & & Web blight & Rhizoctonia solani \\
\hline & Cucurbita sp. & Pumpkin & Powdery mildew & Podosphaera xanthii \\
\hline
\end{tabular}


Table 1. Continuation.

\begin{tabular}{|c|c|c|c|c|}
\hline \multirow[b]{2}{*}{ Municipality } & \multicolumn{2}{|c|}{ Cucurbit } & \multirow[b]{2}{*}{ Disease } & \multirow[t]{2}{*}{ Pathogen } \\
\hline & Scientific name & Common name & & \\
\hline \multirow[b]{2}{*}{ Inajá } & \multirow[b]{2}{*}{ Citrullus lanatus } & Watermelon & Powdery mildew & Podosphaera xanthii \\
\hline & & & Alternaria & Alternaria sp. \\
\hline \multirow{3}{*}{ Petrolândia } & Cucumis melo & melon & Anthracnose & Colletotrichum sp. \\
\hline & Cucurbita sp. & Pumpkin & Powdery Mildew & Podosphaera xanthii \\
\hline & Citrullus lanatus & Watermelon & Powdery mildew & Podosphaera xanthii \\
\hline \multirow[b]{2}{*}{ Salgueiro } & \multirow[b]{2}{*}{ Cucurbitasp. } & Pumpkin & Downy mildew & Pseudoperonospora cubensis \\
\hline & & & Powdery mildew & Podosphaera xanthii \\
\hline \multirow{2}{*}{ Serra Talhada } & Citrullus lanatus & Watermelon & Powdery mildew & Podosphaera xanthii \\
\hline & Cucurbita sp. & Pumpkin & Powdery mildew & Podosphaera xanthii \\
\hline
\end{tabular}

Table 2. Survey of plant viroses present in cucurbit samples collected in the hinterland municipalities in the state of Pernambuco.

\begin{tabular}{|c|c|c|c|c|c|c|c|c|}
\hline \multirow{2}{*}{ Species } & \multicolumn{3}{|c|}{ Samples } & \multicolumn{5}{|c|}{ Samples infected } \\
\hline & Rated * & Unfected & Mixed infections & CMV & PRSV-W & WMV & ZYMV & SqMV \\
\hline Citrullus lanatus & 22 & 14 & 5 & - & 6 & 12 & 6 & - \\
\hline Cucurbita sp. & 9 & 6 & 4 & - & 1 & 4 & 3 & - \\
\hline Cucumis melo & 50 & 28 & 21 & - & 8 & 14 & 22 & - \\
\hline TOTAL & 81 & 48 & 30 & & 15 & 30 & 31 & - \\
\hline \multicolumn{9}{|c|}{ By municipality } \\
\hline Custódia & - & - & - & - & - & - & - & - \\
\hline Floresta & 30 & 19 & 12 & - & 6 & 9 & 10 & - \\
\hline Ibimirim & 16 & 9 & 4 & - & 5 & 9 & 2 & - \\
\hline Inajá & 14 & 7 & 7 & - & 1 & 7 & 7 & - \\
\hline Petrolândia & 21 & 13 & 7 & - & 3 & 5 & 12 & - \\
\hline Salgueiro & - & - & - & - & - & - & - & - \\
\hline Serra Talhada & - & - & - & - & - & - & - & \\
\hline TOTAL & 81 & 48 & 30 & 0 & 15 & 30 & 31 & \\
\hline
\end{tabular}

Papaya ring spot virus type watermelon (PRSV-W), Watermelon mosaic virus (WMV), Zucchini yellow mosaic virus (ZYMV), Cucumber mosaic virus (CMV) and Squash mosaic virus (SqMV); (-): Lack of information.

In this work, the indirect ELISA tests have not shown positive samples for Cucumber mosaic virus (CMV) in any of the sampled municipalities. However, the genus potyvirus was present in all localities sampled for viruses. In the agar doublediffusion test, the squash mosaic virus (SqMV) was not present, either. Studies by Oliveira et al. (2000) in northeast Brazil, Moura et al. (2001) in the state of Maranhão, Halfeld-Vieira et al. (2004) in Roraima and Silveira (2009) in the Lower Basin of the São Francisco river did not show the occurrence of squash in significant amounts in serological survey studies, indicating low or no prevalence of such viruses in the study area.

ZYMV and WMV predominated over PRSV$\mathrm{W}$ in cucurbit-producing localities where the samples were collected in the hinterland municipalities of Pernambuco. However, WMV and PRSV-W were present in samples with lower occurrence. ZYMV was identified in a significant degree of intensity: it was present in $42.8 \%, 50 \%$ and $78.6 \%$ of the infected samples of watermelons; pumpkins and melons, respectively (Table 2). This virus has been identified and reported in various regions of Brazil, e.g., in Maranhão by Moura et al. (2001); Roraima by Halfeld-Vieira et al. (2004); in the Lower Basin of the São Francisco river by Silveira et al. (2009) and more recently by Alencar et al. (2012), who confirmed the presence of this virus in $44 \%$ of the leaf samples in a survey on cucurbits in the state of Tocantins.

In the municipality of Floresta, there was a 
predominance of ZYMV and WMV, by approximately $53 \%$ and $48 \%$ of infected samples respectively, and $31.6 \%$ were positive for PRSV-W. In samples collected in the municipality of Ibimirim, there was predominance of WMV and PRSV-W with $100 \%$ and $56 \%$ of contaminated samples, respectively, in contrast to $22 \%$ of the samples infected with ZYMV (Table 2).

The ZYMV and WMV viruses were in $100 \%$ of the infections of the samples in Inajá. PRSV-W accounted for $14.2 \%$ of the infected samples (Table 2). In the municipality of Petrolândia, ZYMV was identified in $92.31 \%$ of the infected samples, WMV in $38.4 \%$ and PRSV-W in $23 \%$ (Table 2).

The precise identification of plant viruses which are present in the main producing regions of cucurbits in the hinterland of the state of Pernambuco sheds light on their distribution in different crops and regions of the state, thus allowing the implementation of virus control strategies.

\section{CONCLUSIONS}

Differences were found in the productive profile of local producers: squash and pumpkins are grown mainly by smallholders, while melons and watermelons are mostly commercially produced in mid-sized and large farms.

Several pathogens occur in cucurbit crops in the study area, especially powdery mildew and viroses PRSV-W, WMV and ZYMV.

\section{REFERENCES}

ALENCAR, N. E. et al. Identificação biológica e molecular de vírus detectados em espécies de cucurbitáceas provenientes do Estado do Tocantins. Journal of Biotechnology and Biodiversity, Gurupi, v. 3, n. 1, p. 32-37, 2012.

ALMEIDA, A. M. R.; LIMA, J. A. A. Princípios e técnicas de diagnose em fitovirologia. Brasília/ Fortaleza: Publicação SBF, 186 p. 2001.

FILGUEIRA, F. A. R. Novo manual de olericultura: agrotecnologia moderna na produção e comercialização de hortaliças. Viçosa, MG: UFV. 2008. 421 p.

HALFELD-VIEIRA, B. A. et al. Identificação sorológica de espécies de potyvirus em melancia, no estado de Roraima. Fitopatologia Brasileira, Brasília, v. 29, n. 6, p. 687-689, 2004.

KUROSAWA, C.; PAVAN, M. A. Doenças das cucurbitáceas. In: KIMATI, H. et al. (Eds.). Manual de fitopatologia. São Paulo: Ceres, 1997. p. 325-
337.

LIMA, M. F.; ALVES, R. C. Levantamento de vírus em cucurbitáceas no Brasil, no período 2008 -2010. Empresa Brasileira de Pesquisa Agropecuária Embrapa Hortaliças Ministério da Agricultura, Pecuária e Desenvolvimento. Boletim de Pesquisa e Desenvolvimento, n. 76, dez. de 2011.

MDIC/SECEX. Ministério do Desenvolvimento, Indústria e Comércio Exterior. Aliceweb: dados das Exportações brasileiras por região. Disponível em: $<$ http://www.aliceweb.desenvolvimento.gov.br $>$.

Acesso em: 10 out. 2015.

MENEZES, M; SILVA-HANLIN, D. M. W. Guia prático para fungos fitopatogênicos. Recife, $\mathrm{PE}$ : UFRPE, Imprensa Universitária, 106 p, 1997.

MOURA, M. C. C. L. et al. Identificação sorológica de espécies de vírus que infetam cucurbitáceas em áreas produtoras do Maranhão. Fitopatologia Brasileira, Brasília, v. 26, n. 1, p. 90-92, 2001.

OLIVEIRA, V. B. et al. Caracterização biológica e sorológica de isolados de potyvirus obtidos de cucurbitáceas no Nordeste brasileiro. Fitopatologia Brasileira, Brasília, v. 25, n. 4, p. 628-636, 2000.

REIS, A. et al. Caracterização do perfil patogênico de isolados de Podosphaera xanthii obtidos em cucurbitáceas na região Nordeste do Brasil. Horticultura Brasileira, Brasilia, v. 23, n. 1, p. 362. 2005.

ROSSMAN, A. Y., PALM, M. E.; SPIELMAN, L. J. A literature guide for the identification of plant pathogenic fungi. St. Paul. APS Press. 1994.

SANTI, A. et al. Desempenho e orientação do crescimento do pepino japonês em ambiente protegido. Horticultura Brasileira, Brasília, v. 31, n. 4, p. 649-653, 2013.

SANTOS, G. R.; CAFÉ-FILHO, A. C. Ocorrência do crestamento gomoso do caule em melancia no Tocantins causado por Didymella bryoniae. Fitopatologia Brasileira, Brasília, v. 31, n. 2, p. 208 $-208,2006$.

SILVA, V. A. V.; SILVEIRA, E. B.; MARIANO, R. L. R.. Sobrevivência de Acidovorax avenae subsp. Citrulli em meloeiro. Fitopatologia Brasileira, v 31, n. 4, p.384, 2006.

SILVEIRA, L. M. et al. Levantamento sorológico de vírus em espécies de cucurbitáceas na região do submédio São Francisco, Brasil. Tropical Plant Pathology, Brasília, v. 34, n. 2, p. 123-126, 2009. 